\title{
Language Complexity in Historical Perspective: The Enduring Tropes of Natural Growth and Abnormal Contact
}

\author{
James McElvenny* \\ SFB 1187 "Medien der Kooperation", University of Siegen, Siegen, Germany
}

Focusing on the work of John McWhorter and, to a lesser extent, Peter Trudgill, this paper critically examines some common themes in language complexity research from the perspective of intellectual history. The present-day conception that increase in language complexity is somehow a "natural" process which is disturbed under the "abnormal" circumstances of language contact is shown to be a recapitulation of essentially Romantic ideas that go back to the beginnings of disciplinary linguistics. A similar genealogy is demonstrated for the related notion that grammatical complexity is a kind of "ornament" on language, surplus to the needs of "basic communication." The paper closes by examining the implications of these ideas for linguistic scholarship.

Keywords: language complexity, language contact, intellectual history, history of linguistics, language classification, comparative-historical linguistics, Romanticism, German idealism

OPEN ACCESS

Edited by:

Marcin Maria Kilarski,

Adam Mickiewicz University, Poland

Reviewed by:

Luigi Rizzi,

Université de Genève, Switzerland

Micaela Verlato,

Germany

*Correspondence:

James McElvenny

james.mcelvenny@mailbox.org

Specialty section:

This article was submitted to

Language Sciences,

a section of the journal

Frontiers in Communication

Received: 26 October 2020 Accepted: 18 February 2021

Published: 26 April 2021

Citation:

McElvenny J (2021) Language Complexity in Historical Perspective:

The Enduring Tropes of Natural

Growth and Abnormal Contact.

Front. Commun. 6:621712.

doi: 10.3389/fcomm.2021.621712

\section{INTRODUCTION}

Linguistics as an academic discipline was born in the nineteenth century. Since that time, linguistics has expanded in empirical scope and undergone repeated conceptual renewals. Despite these developments, however, there is a widespread tendency among linguists to return to premises and prejudices first acquired in the formative years of their field. One area in which this atavistic impulse is particularly visible is recent discussions of "language complexity." The ranking of languages according to their supposed level of grammatical elaboration was a mainstay of early disciplinary linguistics. In the second half of the nineteenth century, the popularity of this pursuit gradually declined, until it fell into definitive disrepute around the middle of the twentieth century. But the 1980s saw a resurgence of interest in such questions, which has continued to the present day (for a sketch of this history, see Joseph and Newmeyer, 2012).

Recent writings on language complexity not only revive old questions, but in their contours recapitulate many features of the nineteenth-century debates. In this paper, we examine some recent contributions to language complexity research and compare them to their nineteenth-century predecessors to reveal the continuities and parallels. We ask what underlying beliefs, whether articulated explicitly or maintained subconsciously, may have driven past and present scholars to arrive at such similar positions.

The discussion of present-day views of language complexity in this paper focuses on the writings of John McWhorter (in particular McWhorter, 2001; McWhorter, 2007), although the work of other contemporary scholars-such as Peter Trudgill (Trudgill, 1989; Trudgill, 2009; Trudgill, 2011)—is also addressed at several points. McWhorter receives such great attention because, among current accounts of language complexity, his is the most comprehensive. It must be noted that even though this paper is frequently probing and critical in tone it is not intended to be polemical. 
We begin in Section 2 below with an exposition of McWhorter's theory of language complexity, concentrating on the way in which he characterizes complexity and the explanatory factors to which he appeals. Sections 3-5 are then dedicated to illustrating the parallels between contemporary and historical accounts: Section 3 treats the "growth" of language complexity, Section 4 its "decline," and Section 5 the idea that grammatical complexity is a kind of "ornament." Finally, Section $\mathbf{6}$ offers some hypotheses on why these parallels are maintained and what implications they may have for linguistic research.

\section{NATURAL COMPLEXITY, ABNORMAL TRANSMISSION}

The germ out of which McWhorter's work on language complexity has grown is his notion of the "Creole Prototype" (presented, among other places, in McWhorter, 1998; McWhorter, 2001), a set of synchronically identifiable structural properties that supposedly define creole languages as a typological class. From his earliest presentations onwards, McWhorter has argued that "the world's simplest grammars are creole grammars" (the title of his 2001 paper) and that this alleged simplicity arises from a "break in transmission" through pidginization that has occurred in the recent history of creole languages. As McWhorter $(2001,126)$ himself points out, his proposal for a creole prototype reiterates a theme familiar in creolistics in which creoles are seen as languages stripped down to the bare linguistic essentials.

The effort to describe creoles as a typological class has received considerable pushback. DeGraff (2001; 2003), for example, decries what he calls "creole exceptionalism," the idea that "creole languages-thus creole speakers-are deeply special, with genealogical and structural properties that are fundamentally distinct from their non-creole counterparts" (DeGraff, 2001, 228). A necessary implication of this view, according to DeGraff, is that creoles are degenerate languages and represent a reversion to a putative primitive state. By contrast, DeGraff (ibid.) argues that creoles are the product of ordinary linguistic processes and, as such, are structurally indistinguishable from all other languages. What delimits creoles as a category are merely the specific socio-historical circumstances under which they have emerged.

While DeGraff denies any special typological status to creoles and considers them fully normal, McWhorter attempts to rescue his argument by extending the scope of the abnormal. In more recent work, McWhorter $(2007,268)$ introduces the category of "Non-hybrid Conventionalized Second Language" (NCSL). This category-which includes such languages as English, Malay, Mandarin and Modern Arabic-represents languages that are "significantly less complex [...] than their sisters" as a result of "significant non-native acquisition in their histories" (ibid.). That is, NCSLs supposedly exhibit simpler grammars than the languages to which they are most closely related.

In a nutshell, McWhorter $(2007,4-5 ; 2011,1-2)$ argues that the "natural" course of language development is to continually accrete complexity in grammar. In "normal" language transmission, in which the language is learned by children as a first language, this complexity is passed down intact from generation to generation, and expanded upon with each generation. In "abnormal" transmission, by contrast, this complexity is attenuated. Abnormal transmission occurs when there is an influx of adult learners into the speech community who are unable to master the grammatical nuances of the language: the adults' failure to properly command the grammar leads to its simplification. Creoles-which, on McWhorter's understanding, have emerged from pidgins-represent the most extreme case, in which at one point the vast majority of language learners were adults. As a result, creole grammar is the most reduced. NCSLs are an intermediate case, where there was still a high degree of adult language acquisition, but less so than in the pidginization scenario. As such, NCSLs display a mid-range reduction in linguistic complexity.

McWhorter devotes considerable effort to devising rigorous metrics for complexity, and arrives at three main variables: "overspecification," "structural elaboration" and "irregularity" (see McWhorter, 2007, 21-35; McWhorter, 2011, 2-3). Overspecification refers to the demands grammars place on speakers to spell out various distinctions, such as number and gender marking on nouns, tense, aspect and mood marking on verbs, and so on. Structural elaboration refers to how descriptively tractable a language is: this metric is essentially a tally of the number of basic units and rules that a grammarian would have to posit in order to write a description of the language. Irregularity is a measure of the exceptions and anomalies that defy orderly rules and must simply be listed separately. McWhorter's claim is that creoles will always score lowest on these measures, NCSLs will sit somewhere in the middle, and "normal" languages will achieve high scores on all of these points.

McWhorter's view of complexity is a product of the grammarian's gaze: the linguistic features he targets are the phonology, morphology and syntax described in the average reference grammar. To his credit, McWhorter (2007, 52-55) acknowledges that there may be dimensions to complexity beyond those recorded in traditional grammars, such as pragmatic effects and modulating devices like intonation. However, McWhorter $(2007,53)$ maintains that the structural properties he identifies represent "concrete complexity." These are allegedly aspects of language which are difficult for adult learners to master under any circumstances and which are measurably susceptible to reduction in contact situations.

Running through McWhorter's account of complexity is the notion that the grammatical features he highlights are somehow "unnecessary to communication" (see McWhorter, 2001, 161; McWhorter, 2007, 4-5 et passim). Exactly what "communication" consists in and what the minimum requirements may be to achieve it are questions he leaves unexamined (cf. DeGraff, 2001, 242-244). The underlying idea seems to be that language complexity, as he has defined it, is a kind of "ornament" (a term that appears, albeit in scare quotes, in the abstract to McWhorter, 2001) on language, an unnecessary decoration maintained by tradition but quickly abandoned when communicative exigencies demand it. 
Let us put aside questions of the validity and appropriateness of McWhorter's metrics and interrogate instead the assumptions that underlie his conception of language complexity. ${ }^{1}$ As was indicated above, his model is predicated on the tension between "natural" complexity and "interruptions" that disturb it. Mustering his biological metaphors, McWhorter (2007, 15) describes the relationship in the following way: "The human grammar is a fecund weed, like grass. Languages like English, Persian, and Mandarin Chinese are mowed lawns, indicative of an interruption in natural proliferation."

The languages McWhorter names here, and which he treats in chapter-length case studies in his 2007 monograph, are exemplars of his NCSL category. Each has supposedly suffered an "interruption" through an episode of "abnormal transmission" at some point in their respective histories, where the speech community was overwhelmed with adult learners. But the degree of interruption was less "abnormal" than in the histories of creole languages, which have passed through a pidgin stage-with universal adult learning-and exhibit a correspondingly greater loss of complexity. On McWhorter's account, this kind of transmission should be considered "abnormal" because it is "less common" in the context of all languages spoken in the world:

I openly assert that creoles are the product of a process of language transmission that is most definitely abnormal. I designate creoles' development as abnormal because the sociohistorical nature of their timeline is much less common than the timeline of thousands of other languages worldwide. That is, their development was not the norm. However, this book has been devoted to arguing that the development of many noncreole languages, including the one I am writing in which is my native language, was also abnormal. The development of both English and Haitian Creole was abnormal-and fascinatingly so (McWhorter, 2007, 274).

McWhorter is at pains to insist that his use of "abnormal" should not be understood as a slur or in any way derogatory. In a note to the paragraph quoted above, he writes:

I will assume that the sentence "creoles are the product of a process of language transmission that is most definitely abnormal" will not be cited in isolation as a demonstration of dismissive attitudes toward creole languages, with an implication that the sentence did not occur within a careful exposition of a case for the claim, including the subsumption within it of languages like English (McWhorter, 2007, 282, n. 2).

But why does McWhorter choose the terms "natural," "interruption," "normal" and "abnormal" to characterize the phenomena he investigates? These are seemingly loaded terms: the opposition of "abnormal" and "interruption" to "normal" and

${ }^{1}$ For detailed discussion of some of the problems involved in measuring putative complexity across languages, see John Joseph's contribution to this volume. "natural" inevitably conjures a picture of deviancy in a world striving for order.

The immediate source for McWhorter's usage would seem to be "normal" and "abnormal" transmission as outlined by Thomason and Kaufman (1988), a book McWhorter cites across his writings on language complexity (e.g., McWhorter, 2007; McWhorter, 2011). In Thomason and Kaufman's model, "normal historical development" occurs under conditions of "normal transmission," where a language is passed down from the elder generation to children. Normal development consists in gradual change brought about by "drift"-that is, diachronic tendencies arising from internal imbalances in the linguistic system-as well as "interference" to varying degrees from neigboring dialects and languages. "Abnormal transmission" is supposed to occur in such situations as pidginization, abrupt creolization, and massive borrowing. In these cases, the linguistic system of the languages will have inevitably broken down (see Thomason and Kaufman, 1988, 9-12, 211-213).

It could perhaps be argued that Thomason and Kaufman's use of "normal" and "abnormal" is not necessarily pejorative because the terms are employed within a defined theoretical framework. The aim of their 1988 book is to establish the limits of the comparative method and the family tree model. "Normal" transmission results in changes that can be successfully traced using the comparative method to arrive at "genetic" relationships between languages, while "abnormal" transmission results in "nongenetic development," which is intractable for the comparative method. Within this closed system there is therefore a theory-internal justification for the labels "normal" and "abnormal": "normal" is what accords with the family tree model and "abnormal" what does not (but see DeGraff, 2001, 241-242, n. 22, for a critique).

But McWhorter is one step removed from the comparative concerns of Thomason and Kaufman and, as such, cannot directly appeal to the internal logic of their theory. His notion of "normal" and "abnormal" transmission pertains only to his arguments for language complexity: "normal" is that which preserves complexity, as he defines it, "abnormal" that which destroys it. The connection of his notions of normality to complexity is in fact at odds with Thomason and Kaufman (1988, 46-47), who reject the possibility that any direct structural correlates of "abnormal transmission"-or even of milder "interference"-can be identified.

Not only do Thomason and Kaufman believe that it is impossible to predict the course of contact-induced change, they also deny any absolute metric of complexity. While they acknowledge that some linguistic features may be considered more "marked" and therefore less "natural" in a cross-linguistic sense, they insist that language change, even change stimulated by contact, does not always tend toward less marked forms. Indeed, they subscribe to the traditional structuralist notion that, because each language is a system of interacting sub-systems, it is often difficult to quantify the overall complexity of a language: changes that may serve to simplify one aspect of a language will invariably cause complexification in another sub-component of that language (see Thomason and Kaufman, 1988, chap. 2).

In the passage quoted above, McWhorter $(2007,274)$ justifies his use of "abnormal" with the claim that the "sociohistorical 
nature of [the creole and NCSL] timeline is much less common than the timeline of thousands of other languages worldwide." Quite apart from the notoriously difficult problem of identifying discrete "languages," which McWhorter does not even address, he offers this argument in the absence of any statistical data quantifying the world's languages and their respective sociohistorical circumstances. ${ }^{2}$ If, on the other hand, McWhorter's unit of comparison is the kind of speech community to which most human language speakers around the world are exposed, then his notion of "normal" becomes self-defeating: it is precisely those contact varieties with the greatest number of speakers that are the most abnormal on his definition.

But there are hints that McWhorter's notions of "natural" and "abnormal" have deeper roots and perpetuate much older ideas. According to McWhorter $(2007,13)$, the socio-cultural circumstances engendering the "abnormal transmission" that destroys "natural" complexity have emerged only after the development of agriculture in the "post-Neolithic revolution." Stone Age hunter-gatherers are therefore taken to be somehow in a pristine state of nature, while the fateful technology of agriculture has led us into the abnormality of modern contact. These two threads of his story-"natural" complexity and "abnormal" contact-have clear antecedents in the early history of disciplinary linguistics.

\section{LINGUISTIC PERFECTION}

Although couched in rather different terms from present-day discussions, the notion that increasing complexity in some way represents the natural course of development in human language is an idea deeply ingrained in the linguistics of the early to midnineteenth century. In this period, the focus lay for the most part on morphology and its putative links to language evolution (see Morpurgo Davies, 1975).

For the early comparative-historical grammarians, it was the similarities in the rich inflectional forms across the classical languages of Europe and India, with their shared convolutions and irregularities, that inspired their project and served as its chief source of evidence. Friedrich Schlegel (1772-1829), whose writings are often attributed a central role in inaugurating comparative-historical grammar (see Morpurgo Davies, 1998; chap. 3), saw inflection as the prerogative of Indo-European languages (Schlegel, 1808). Inflection makes the IndoEuropean languages "organic" (organisch) in structure, in contrast to all other languages of the world, which he held to be merely "mechanical" (mechanisch).

Schlegel's distinction between the "organic" and "mechanical" was part of an extended biological analogy. The so-called organic

\footnotetext{
${ }^{2}$ All large-scale linguistic databases are faced with the problem of securing a scientifically valid and statistically representative sample of the world's languages. The compilers of the World Atlas of Language Structures (WALS), for example, point out this difficulty and acknowledge that their sample is not entirely satisfactory, limited as it is by what language descriptions are available to them and what aspects of each language these descriptions treat (see Comrie et al., 2013).
}

languages with their inflections were supposed to be of a kind with living organisms: inflections grow out of the "living germ" (lebendiger Keim) of the word root, while the words of "mechanical" languages are merely cobbled together out of roots and affixes and so lack any true integration. In the most extreme cases, even affixes are missing and sentences are simply arrangements of bare word roots (Schlegel, 1808, 50-52). The opposition Schlegel sets up between the "organic" and "mechanical" draws on a conceptual pair from Immanuel Kant's discussion of teleology, which elevates living organisms to "natural purposes." That is, living organisms exist for themselves, while the purely mechanical world is subordinate to externally determined ends (see Ginsborg, 2019, Section 3).

On one level Schlegel therefore tapped into discourses popular in contemporary German philosophy and the esthetic preferences of the early Romantic movement, with its exaltation of the natural world and suspicion of purely functional human invention (see Richards, 2002; Morpurgo Davies, 1998, 86-88). The love of the "organic" lies also at the heart of the scientific justification of Schlegel's project: his comparative grammar was based explicitly on comparative anatomy (see Schlegel, 1808, 28), which made great advances in this period and rose to the status of a model science. The rich inflections of the "organic" languages provide much better evidence to the comparativist than the loose "mechanical" forms found elsewhere, which seem "like a heap of atoms, which the wind of chance can easily drive apart or bring together" (wie ein Haufen Atome, die jeder Wind des Zufalls leicht aus einander treiben oder zusammenführen kann; Schlegel, 1808, 51).

The dichotomy between "organic" and "mechanical" languages set up by Schlegel was soon challenged by proponents of the "agglutination theory," which held that morphological classes are not absolute but rather arise diachronically. According to this theory, inflectional forms originally began as separate words that gradually became more closely bound to word roots, first as affixes and then finally as inflections. A key source for this doctrine is Franz Bopp's (1791-1867) account of the emergence of IndoEuropean verb endings (e.g. Bopp, 1816, 147-151). It should be noted, however, that Bopp's account was directed toward the analysis of Indo-European verb forms and was not intended as a contribution to typology (see Morpurgo Davies, 1998, 133-135; Jespersen, 1922, 54-56).

The recasting of agglutination theory in a typological mold revolved around a particular reading, widespread in the nineteenth century, of the work of Wilhelm von Humboldt (1767-1835). Humboldt (1998 [1836], 151) maintained that there is an "idea of perfection in language" (Idee der Sprachvollendung), a telos that the "language-forming force in humanity" (die sprachbildende Kraft in der Menschheit) strives to achieve. Language is not just a passive medium of expression, but the "forming organ of thought" (das bildende Organ des Gedanken; Humboldt, 1998 [1836], 180). The development of linguistic forms represents the dialectic interplay between thought and language as each shapes the other (see Trabant, 1986; Trabant, 2012, chap. 8).

According to Humboldt (1843 [1822], 282-283, 296-283; cf. Humboldt, 1998 [1836], 281-283; see also Trabant, 2012, 
143-147), it is possible to identify distinct stages of development as languages move toward perfection. At the lowest stage of development, concepts find representation in the linguistic form, but the relations between the concepts are only implied through the ad hoc use of word order or the improvised repurposing of words with a full denotational meaning. At the second stage, word order becomes more fixed and certain words to express relations are conventionalized. At the third stage, the relational elements become bound, turning into affixes. Finally, at the last stage, the affixes become integral parts of the word; that is, inflection emerges. Inflected words combine concepts and their relations to the rest of the sentence into single integrated packages, thereby providing the best representation of the underlying structure of thought.

Humboldt's scheme was not intended as a catalog of essentialist language types but rather an account of grammatical processes that may criss-cross languages. A predominantly inflectional language, for example, may still make use of word order, grammatical particles and other devices from earlier stages of development. In addition, Humboldt insisted that there is no single measure of this scale of perfection: the course of development of individual languages is a matter of historical contingency and is, in its details, unpredictable (Humboldt, 1843 [1822], 269-270). Furthermore, despite whatever structural deficiencies a language may possess, a skilled user of that language will be able to effectively express any ideas in it (Humboldt, 1843 [1822], 280-281).

However, Humboldt was widely interpreted as putting forward a deterministic scheme of language evolution, the stages of which could be observed in presently existing languages (cf. Coseriu, 1972). The culmination of this kind of interpretation, with a reassertion of parallels to biology, is the theory of linguistic "morphology" (Morphologie) set out by August Schleicher (1821-1868), which offered a classification of word forms in the world's languages linked to a theory of language evolution (see Schleicher, 1859; Schleicher, 1860, $33-71)^{3}$

The evolutionary component of Schleicher's theory is often described as "Darwinian." DeGraff (2001), for one, applies this label to Schleicher's thought and work he sees following in its footsteps, including McWhorter (2001). While it is true that Schleicher, toward the end of his career, attempted to align his work with Darwinian doctrine (most notably in Schleicher, 1863), his proposals for morphology predate this connection and were in fact not entirely compatible with Darwin's views (see Alter, 1999; McElvenny, 2018a). ${ }^{4}$ Schleicher's thought was more directly influenced by idealist Naturphilosophie, in particular the theory of plant and animal "morphology" advanced by Johann Wolfgang von Goethe (1749-1832), which was later taken up and

\footnotetext{
${ }^{3}$ Schleicher's use of "morphology" in this sense predates the present-day generic usage of this term in which it describes all processes that take place at the word level.

${ }^{4}$ DeGraff is not unaware of the complex relationships between linguistic and biological theory in this era. In a footnote, DeGraff $(2001,218, n$. 4) offers a multiply hedged designation buttressed by scare quotes to label the linguistic theories of this period: “(pre-, post-, quasi-)‘Darwinian' linguistics.”
}

developed further in a "monist" mode by Ernst Haeckel (1834-1919; see Richards, 2008, Appendix 1).

Biological morphology aimed at describing the development of living organisms, on both an individual ontogenetic level and a species-wide phylogenetic level, through the comparison of anatomical forms. In the early idealist varieties of morphology, both ontogenetic and phylogenetic development were taken to be driven by immanent forces within organisms. Schleicher's linguistic morphology adopted this immanent conception of development to cast the gradual emergence of inflection as a natural process. Schleicher $(1860,33-35)$ imagined that languages develop through stages from the bare roots of the isolating languages, the affixes of agglutinative languages, and finally to inflectional forms. ${ }^{5}$ In line with his interpretation of Humboldt, Schleicher $(1860,18)$ felt that language, as the "concept of the phonetic body of thought" (der Begriff [...] des lautlichen Leibes des Denkens), strives to the particular "perfection" (Vollkommenheit) manifested in inflection.

As the survey presented in this section shows, the central premise of McWhorter's theory that increase in complexity is a "natural" tendency in language recapitulates in many ways nineteenth-century ideas that fetishized inflectional morphology as the natural endpoint of language development. Schlegel, at the very beginning of the century, imagined that only those languages with inflection are "organic"; that is, only inflecting languages are true organisms, "natural purposes" in a Kantian sense, in contrast to all others, which are merely "mechanical." Schleicher, reinforcing the biological analogy and tying it to his interpretation of Humbolt, saw the development of inflection as the product of a natural striving toward "perfection" (Vollendung, Vollkommenheit) in language.

The nineteenth century's almost exclusive focus on inflection is not foreign to McWhorter. While current discussions of complexity, including McWhorter's, draw in other aspects of language-such as phonology, lexicon, semantics and pragmatics-morphology, and in particular inflectional morphology, continues to loom large. McWhorter (2007, 35-45) puts some effort into justifying the role inflection plays in his account of complexity. He insists that the attention he devotes to inflection is not mere Eurocentrism or, on the other hand, exoticization of this feature on the part of a speaker of Modern English, a language that has largely retreated from inflection. He maintains rather that inflection is indeed a linguistic feature that can be shown objectively to manifest the three dimensions of complexity-overspecification, structural elaboration and irregularity-that he identifies.

In McWhorter's appeals to the "natural" growth of complexity in languages we therefore hear echoes of nineteenth-century ideas about the evolution of language as encapsulated in the morphological typologies of the period. The historical parallels continue if we compare McWhorter's account of the loss of

\footnotetext{
${ }^{5}$ Schleicher struck a very modern note, however, in distinguishing between the typology of languages and their genealogical relatedness. Schleicher (1859, 37-38, 1860) said that languages can belong to different morphological classes and still be related in a genealogical sense.
} 
complexity in "abnormal" cases of language contact with nineteenth-century views on the decline of inflection.

\section{CORRUPTING CONTACT}

Even though the nineteenth-century linguistic imagination was dominated by the idea that the growth of inflection represented a natural tendency in language, scholars in this period were still very much aware of the loss of inflection and increasing reliance on periphrastic and syntactic constructions attested in many modern European languages-above all the Romance and Germanic vernaculars-when compared with their classical ancestors. This development was usually described in terms of the change from "synthetic" classical languages to "analytic" modern vernaculars. This usage was widespread, but one of the earliest oppositions of the two terms in this context would seem to be in an 1818 essay of August Wilhelm Schlegel (1767-1845), the elder brother of Friedrich Schlegel (on the connections of these terms to philosophical discourse, see McElvenny, 2017; McElvenny, 2018b, 67-87). A frequently invoked cause of the move toward analyticity was the influence of contact between peoples, presenting us with another striking parallel between nineteenth-century and present-day thought on questions of language complexity.

Once again, Schleicher, inspired by a particular reading of Humboldt, provides an excellent example of these views. Humboldt himself did not believe in any directionality in the development of linguistic forms, or even that diachronic changes such as the apparent loss of inflection in modern European vernaculars represent a reconfiguration of the fundamental organizational principles of their grammars (see Di Cesare in Humboldt, 1998 [1836], 81-85; Trabant, 1990, chap. 6). But he did imagine two distinct periods in the evolution of language. In the first of these, the "sound-creating drive of language" (lautschaffender Trieb der Sprache) creates new grammatical forms in accordance with the structural principles of the language. In the second period, this drive declines and speakers' energy is directed away from the creation of new forms and instead toward the reshaping and repurposing of existing forms (Humboldt, 1998 [1836], 279).

Schleicher tied the apparent rise of synthetic forms in classical languages followed by the shift to analytic structures in their modern descendants to Humboldt's two evolutionary periods. He posited a "pre-historic period" (vorhistorische Periode) in which the grammatical forms of languages-and the allegedly intertwined cognitive capacities of their speakers-grow along the continuum of isolating to inflectional, and a "historical period" (historische Periode) in which languages degenerate from synthetic to analytic (Schleicher, 1860, 37). According to Schleicher, the degree to which a language degenerates in the historical period is directly proportional to how involved its speakers are in history:

It is even possible to prove objectively that history and language development stand in an inverse relation to one another. The richer and grander the history, the faster the degeneration of language; the poorer, slower and more sluggish the history, the more faithfully preserved is the language (Schleicher, 1860, 35). ${ }^{6}$

A key measure of a people's involvement in history is the degree of contact they have with other peoples (cf. DeGraff, 2001, 219, n. 5). "Great historical movements," Schleicher $(1860,36)$ states, "cause particularly striking changes in language" (Große geschichtliche Bewegungen haben nämlich besonders auffallende Veränderungen der Sprache im Gefolge). As an example of such a historical movement, Schleicher names the Völkerwanderung, the usual German designation for the great migrations and "barbarian" invasions of the Roman Empire in Late Antiquity.

For Schleicher the reshaping of languages in this way was largely a matter of internal developments (von innen heraus) set off by the "impulse" (Anstoß) of historical movements, and not the result of borrowing between languages (Schleicher, 1860, 36). In this respect, Schleicher again builds on themes in Humboldt's writings: Humboldt denied that the modern Romance vernaculars had emerged from a mixture of Latin with Germanic dialects-as had been argued by August Wilhelm Schlegel (1818), among others-and indeed denied that the Romance vernaculars were different in their fundamental structural principles from Latin. However, Humboldt did claim that the observable changes in the outer grammatical forms of the Romance vernaculars were spurred on by societal and cultural change resulting from the immigration of foreign peoples into Roman territories (see Trabant, 1990, 128-134). Both Humboldt and Schleicher therefore point to intercultural contact as a trigger of language change.

The division of language evolution into pre-historic and historic periods reflects a trope of the late Enlightenment and early Romanticism in which an imagined pre-historic era is contrasted to contemporary civilized life. On this account, prehistoric humans-and "uncivilized" peoples today-live in an idyllic state of nature, while our modern world of culture is characterized by depravity and degeneration. This view is classically associated with Jean-Jacques Rousseau (1712-1778), but became so widespread as to be a cliché (see Bollenbeck, 2007). Schleicher's vision of pre-historic language growth and historical decline, based on his reading of Humboldt, is essentially a projection of this attitude onto language. ${ }^{7}$

McWhorter's model of language contact as an engine of grammatical simplification similarly divides human history into two distinct ages. As discussed in Section 2 above,

\footnotetext{
${ }^{6}$ Original quotation: "Es läßt sich sogar objektiv nachweisen, daß Geschichte und Sprachentwicklung in umgekehrtem Verhältnisse zu einander stehen. Je reicher und gewaltiger die Geschichte, desto rascher der Sprachverfall; je ärmer, je langsamer und träger verlaufend jene, desto treuer erhält sich die Sprache."

${ }^{7}$ There is a tradition, since at least Jespersen (1922, 71-76), of describing Schleicher's conception of language growth and decline as being inspired by the philosophy of history of Georg Wilhelm Friedrich Hegel (1770-1831; cf. Koerner, 1989). While Hegel most certainly influenced Schleicher's thought, he is not the sole-and perhaps not even the most signficant-influence in this respect. Schleicher's pessimism is out of step with the overarching optimism of Hegel's philosophy of history and its exaltation, in its mature form, of the Prussian present (see Bollenbeck, 2007, 122-133).
} 
"abnormal transmission" that leads to the destruction of "natural" linguistic complexity is taken to be a phenomenon found only in societies that have gone through the "postNeolithic revolution" and developed agriculture. Among present-day language complexity researchers, McWhorter is not alone in this contention: Trudgill (Trudgill, 2009, 109; Trudgill, 2011, 169), for example, also identifies the mass adult language learning that is supposed to cause simplification as "a mainly post-neolithic and indeed a mainly modern phenomenon."

Trudgill (1989; 2009; 2011), who is cited by McWhorter on occasion, makes slightly more nuanced use of such terms as "normal," "abnormal" and "natural." His writings are in fact intended as a critique of the opposite assumption that the complex grammatical forms of smaller, isolated languages are somehow abnormal in comparison to the grammatical sleekness of languages used in wide-scale communication. Trudgill (1989, 233) claims that "high-contact linguistic situations have become much more common in recent times" and that it "may therefore be increasingly likely that our views as linguists of what is normal in linguistic change will be skewed toward what happens in highcontact situations, unless we are careful." This view is predicated on the belief that

When it comes to contact, the present is not like the past, and it is by investigating isolated languages that we are most likely to gain insights into the sorts of linguistic changes that occurred in the remote past (Trudgill, 1989, 236; see also Trudgill, 2009, 109; Trudgill, 2011, 168).

At this point it would be helpful to examine the fate of nineteenth-century schemes of linguistic growth and decline. In the second half of that century, such schemes were largely abandoned as theoretically untenable. A major factor here was the reception in linguistics of uniformitarian doctrine from geology (see Christy, 1983). According to uniformitarianism, the most elegant-and most valid-mode of explanation in accounting for historical change is to assume the gradual action of constant forces, rather than postulating distinct ages in which different principles are at play.

In the realm of diachronic typology, the new uniformitarian outlook led to the rejection of notions of grammatical growth and decline in favor of the "spiral" view familiar from presentday grammaticalization theory (see Lehmann, 2015 [1982]): the image of diachronic language development as a spiral had already been put forward in the late nineteenth century by Georg von der Gabelentz (1840-1893; Gabelentz, 2016 [1891], 269), among others (see Plank, 1992; McElvenny, 2020). On this

${ }^{8}$ Trudgill also employs Bailey (1982) coinages "connatural" and "abnatural," terms which seemed to have enjoyed some currency in the 1980s. In short, "connatural" changes are those that occur when languages are "left alone"; that is, they are meant to arise from internal pressures in the linguistic system. "Abnatural" developments arise through language contact. While Bailey insists that both kinds of change are "normal," his conception of language contact exhibits many of the same features as the theories sketched here. account, there is no unidirectional progress along the scale from isolation to inflection followed by degeneration from synthetic to analytic, but rather a continual process of renewal in which languages go through cycles from the synthetic to the analytic pole and back again. For his part, McWhorter (2007, 19-20) does not accept the notion of oscillating complexity as propagated in present-day grammaticalization theory. Grammaticalization cycles, he argues, are local phenomena affecting specific forms and have no bearing on the overall complexity of a grammar.

McWhorter and Trudgill do not deny uniformitarianism: their argument is not that languages themselves pass through different ages but rather that different socio-cultural circumstances, which favor or disfavor certain kinds of linguistic change, are more or less common in different periods (see Trudgill, 2011, 167-169 on this point). Nonetheless, by imagining these circumstances as essentially a distinction between pre- and post-Neolithic societies, McWhorter and Trudgill set up a difference in kind between the pre-historic and modern that undermines uniformitarian principles. It might be prejudiced to assume that present-day large-scale languages are normal and all others abnormal, but it is equally problematic to simply invert this dichotomy. While Trudgill treads carefully in this area, McWhorter charges ahead to imply that non- "modern" societies are somehow still in a wholesome state of nature, that there is on the one side the noble savage and on the other the degenerate cosmopolitan.

\section{ORNAMENTATION}

McWhorter's characterization of complexity as linguistic devices surplus to the needs of "basic communication" also repeats motifs from the nineteenth century. Although inflection was generally treated as the peak of grammatical evolution, the drift away from "synthesis" and toward "analysis" in modern European vernaculars was not always viewed as simple degeneration. Furthermore, languages with grammatical structures considered more complex than inflection-such as incorporation or polysynthesis-were typically seen as possessing an excess of linguistic form.

August Wilhelm Schlegel, in introducing the distinction between "synthetic" and "analytic" languages, was not entirely unsympathetic to the diachronic development this represented. He still assigned "first place" (le premier rang) to the classical synthetic languages, but he also recognized the "degree of perfection" (degré de perfection) which, on his estimation, the analytic languages are capable of achieving (Schlegel, 1818, 15, 17). In similar fashion, Humboldt (1998 [1836], 351), despite his love of inflection, believed that analytic forms are often easier to understand and less ambiguous than their synthetic equivalents (cf. DeGraff, 2001, 219, n. 5). ${ }^{9}$

\footnotetext{
${ }^{9}$ Humboldt (1998 [1836], 351) writes in the original: “[...] da allerdings diese analytische Methode die Anstrengung des Verständnisses vermindert, ja in einzelnen Fällen die Bestimmtheit da vermehrt, wo die synthetische dieselbe schwieriger erreicht."
} 
Indeed, for Humboldt and his followers, it was possible to overshoot perfection in language and end up with an awkward overabundance of grammatical complexity. Inflectional forms may produce the optimal package of concept and relation, but trying to pack any more content into the word results in bloated, confused forms. In the process of incorporation, which Humboldt (1998 [1836], 267-268) examined on the example of Nahuatl, multiple concepts are compressed into a single word, but the relations between these concepts do not find adequate expression. The grammar must resort to including additional concord markers on the verb to bring order into the sentence. On Humboldt's estimation, these markers are so unclear that they are in fact no better than having no indication at all:

Sanskrit indicates each word as a constitutive part of the sentence in a very simple and natural way [through inflection]. The method of incorporation [in Nahuatl] does not do this, but rather, wherever it cannot put everything together as one, allows markers to emerge from the middle of the sentence, much like arrows, which show the direction in which the individual parts must be sought, according to their relationship to the sentence. It does not exempt us from searching and guessing, but in fact through this kind of indication throws us back into the opposite system of no indication. (Humboldt, 1998 [1836], 268). ${ }^{10}$

Schleicher followed Humboldt's judgment on this point (see Schleicher, 1859, 26-27), and explored its implications for language contact. Among "peoples without history"-those imagined tribes that live in an isolated, pre-civilized state-there is often "a true proliferation of linguistic form, an unconstrained linguistic drive that creates constructions which, through their overabundance, make the exchange of ideas with foreign peoples difficult and so seem as an impediment to culture." As an example of this phenomenon, he named the "majority of the Indian languages of America" (Schleicher, 1860, 36). ${ }^{11}$

Toward the end of the nineteenth century, critiques of "excessive" linguistic form were turned against inflection itself. Gabelentz observed that grammars often compel their speakers to say "much more than is necessary for understanding" (weit mehr, als zur Verständigung nöthig ist; Gabelentz, 2016 [1891], 380), and burden them with useless formal paraphernalia. Indo-European

\footnotetext{
${ }^{10}$ Original quotation: "Das Sanskrit bezeichnet auf ganz einfache und natürliche Weise jedes Wort als constitutiven Theil des Satzes. Die Einverleibungsmethode thut dies nicht, sondern läßt, wo sie nicht Alles in Eins zusammenschlagen kann, aus dem Mittelpunkte des Satzes Kennzeichen, gleichsam wie Spitzen, ausgehen, die Richtungen anzuzeigen, in welchen die einzelnen Theile, ihrem Verhältniß zum Satze gemäß, gesucht werden müssen. Des Suchens und Rathens wird man nicht überhoben, vielmehr durch die bestimmte Art der Andeutung in das entgegengesetzte System der Andeutungslosigkeit zurückgeworfen.”

${ }^{11}$ Original quotation: "Bei Völkern ohne Geschichte gewahren wir dagegen nicht selten ein wahres Wuchern der sprachlichen Form, einen Rand und Band überschreitenden Sprachtrieb, der Bildungen hervorruft, die durch übermäßige Fülle den Gedankenaustausch mit fremden Völkern erschweren und so als Hemniß der Cultur erscheinen. Dieß gilt vor allem von den meisten Indianersprachen Amerikas."
}

inflection he called a "defective system" (Defektivsystem), which forces speakers to use a range of arbitrarily differentiated forms across different paradigms to express the same idea (Gabelentz, 2016 [1891], 421). This system is just as extravagant and clumsy as incorporation, and both-as with all grammatical profusion-are the product of an over-active Formungstrieb, an esthetic drive-not a communicative or cognitive force-which expends its excess energy through language play, creating redundant linguistic forms (see McElvenny, 2016).

Otto Jespersen (1860-1943) developed this line of thought further to argue that the move toward analytic structures in modern European vernaculars represents the striving of speakers to achieve the most efficient means of expression (see, e.g., Jespersen, 1922, 323-325; Jespersen, 1960 [1941]). Streamlined, flexible grammars that rely on syntax and shun morphology are more appropriate to the needs of the modern, interconnected world and are a sign of "progress in language" (the title of Jespersen, 1894, his first book). Jespersen, an active participant in the contemporary international language movement, proposed taking advantage of this analytic tendency to consciously construct the optimal language for international communication in modern science, business and diplomacy (see McElvenny, 2017; McElvenny, 2018a, 67-77).

In the same nineteenth-century tradition that offers antecedents of McWhorter's narrative of the rise and fall of language complexity, we find also prefigurations of his notion of complexity as linguistic excess. McWhorter's contention that simplification in contact situations represents the casting off of unnecessary ornament has direct counterparts in the nineteenth century, as scholars considered the emergence of modern "analytic" languages a potential sign of mental and communicative "progress."

\section{CONCLUSION}

Why do the motifs of nineteenth-century language evolution and morphological typology outlined in the previous sections-"natural" growth in complexity, simplification through "abnormal" contact, and grammatical complexity as superfluous decoration-reappear in current work on language complexity? And what do these revivals reveal about the underlying ideology of present-day linguists?

The citation record would suggest that there is no direct transmission of ideas from the nineteenth century to the present. Although his attention has previously been drawn to nineteenth-century precedent, McWhorter does not engage with the historical sources in any serious way. In response to DeGraff s (2001) critique of "Darwinian" linguistics past and present, examined in Section 3 above, McWhorter's (2007, 10-11, 273) insists that his theory of language complexity has no relation to Darwinian evolution, in a passage that makes no reference to the relevant historical sources in linguistics. The one nineteenthcentury figure who appears in McWhorter $(2007,51)$ book is Humboldt, whose discussion of grammatical processes is mentioned briefly in a rather confused fashion and without citation of any primary or secondary sources. Trudgill (e.g., 1989, 232; 2011, 185-186) would seem to have a greater 
awareness of the antecedents, although his texts are still devoid of specific references to historical sources.

In the absence of deep engagement with historical accounts and the intellectual world in which they emerged, it would seem that these revivals represent the inheritance of an old conceptual framework accompanied by its unexamined assumptions. This framework was originally assembled by nineteenth-century scholars acting under the heady influence of Romanticism and idealist philosophy. From those movements the nineteenthcentury scholars derived biological analogies of increase in grammatical complexity as a process of natural growth countered by degeneration brought about through the corrupting influence of civilization.

In Section 2, we observed on the example of Thomason and Kaufman (1988) how the family tree model of language relations gives rise to a view that sees the closed speech community as "normal" and language contact as "abnormal." As we have shown in Sections 3-5, in its earliest nineteenth-century versions this model was already intertwined with ideas about the origin and purpose of grammatical structures and their putative links to cognitive and socio-cultural evolution. In the intervening two centuries, ideas about linguistic structure and-even more so-human evolution have moved on, but aspects of the older conceptions have clearly continued a subcutaneous existence in the discipline of linguistics, only to resurface in the recapitulations of recent scholarship.

The aim of this paper is not to discredit or demolish any scholars' work or even to endorse specific alternatives (as DeGraff, 2001 does in putting forward his alternative "Cartesian-uniformitarian" view). Rather, this paper is intended as a plea to linguists to engage more seriously with intellectual history, in particular as it relates to the history of their own discipline. There is already a vibrant genre of linguistic historiography, which deserves a wider reception among practicing linguists. With respect to the issues addressed in this paper, for example, language complexity researchers might derive some instruction from Hutton's (1999) investigation of the political entanglements of the scholarly constructions "native speaker" and "mother tongue," or from Knobloch's (2011)

\section{REFERENCES}

Alter, S. G. (1999). Darwinism and the Linguistic Image: Language, Race, and Natural Theology in the Nineteenth century. Baltimore: Johns Hopkins University Press. Bailey, C. J. N. (1982). On the Yin and Yang Nature of Language. OCLC: 247943716. (Ann Arbor: Karoma Publ).

Bollenbeck, G. (2007). Eine Geschichte der Kulturkritik: von J.J. Rousseau bis G. Anders. (München: Beck).

Bopp, F. (1816). Über das Conjugationssystem der Sanskritsprache in Vergleichung mit jenem der griechischen, lateinischen, persischen und germanischen Sprache. Frankfurt am Main: Andreäische Buchhandlung.

Christy, T. C. (1983). Uniformitarianism in Linguistics. Amsterdam \& Philadelphia: John Benjamins.

Comrie, B., Dryer, M. S., Gil, D., and Haspelmath, M. (2013). "Introduction," in The World Atlas of Language Structures Online, Editors M. S. Dryer and M. Haspelmath. (Leipzig: Max Planck Institute for Evolutionary Anthropology). (http://wals.info/chapter/s1). exploration of the naturalizing tendencies in present-day "Neo-Darwinist" linguistic discourse and their historical background.

The unexamined use of inherited ideas can lead us to inadvertently propagate prejudices from which we would otherwise recoil. However they may hedge their claims or protest about their scientific neutrality, present-day scholars who advance hypotheses about what is natural and normal in the human world, about supposedly "pre- and post-Neolithic" peoples should pause to consider the origins of their ideas and the implications of their proposals.

\section{DATA AVAILABILITY STATEMENT}

The original contributions presented in the study are included in the article/Supplementary material, further inquiries can be directed to the corresponding author.

\section{AUTHOR CONTRIBUTIONS}

All authors listed have made a substantial, direct, and intellectual contribution to the work and approved it for publication.

\section{FUNDING}

Gefördert durch die Deutsche Forschungsgemeinschaft (DFG) Projektnummer 262513311-SFB 1187 (Funded by the Deutsche Forschungsgemeinschaft (DFG, German Research Foundation)Project-ID 262513311-SFB 1187.)

\section{ACKNOWLEDGMENTS}

I would like to thank John Joseph, Clemens Knobloch and the two reviewers for Frontiers in Communication for their comments on this paper.

Coseriu, E. (1972). "Über die Sprachtypologie Wilhelm von Humboldts: Ein Beitrag zur Kritik der sprachwissenschaftlichen Überlieferung," in Beiträge zur vergleichenden Literaturgeschichte. Festschrift für Kurt Wais zum 65. Geburtstag. Editor J. Hösle (Tübingen: Niemeyer), 107-135.

DeGraff, M. (2001). On the Origin of Creoles: A Cartesian Critique of NeoDarwinian Linguistics. Linguist. Typol. 5, 213-310.

DeGraff, M. (2003). Against Creole Exceptionalism. Language 79, 391-410. doi:10. 1353/lan.2003.0114

Gabelentz, G. v. d. (2016). Die Sprachwissenschaft ihre Aufgaben, Methoden und bisherigen Ergebnisse. OCLC 14, 950016913. doi:10.26530/ oapen_611696

Ginsborg, H. (2019). "Kant's Aesthetics and Teleology," in The Stanford Encyclopedia of Philosophy. Editor E. N. Zalta. Winter 2019 edn (Stanford, USA: Metaphysics Research Lab, Stanford University). https://plato.stanford. edu/archives/win2019/entries/kant-aesthetics/.

Humboldt, W. v. (1843). "Ueber das Entstehen der grammatischen Formen und deren Einfluß auf die Ideenentwicklung," in Wilhelm von Humboldt's gesammelte Werke (Berlin: Reimer), III, 269-306. 
Humboldt, W. v. (1998). "Über die Verschiedenheit des menschlichen Sprachbaues und ihren Einfluß auf die geistige Entwicklung des Menschengeschlechts," in UTB für Wissenschaft Uni-Taschenbücher. Editor D. Di Cesare. (Paderborn: Schöningh).

Hutton, C. (1999). Linguistics and the Third Reich: Mother-Tongue Fascism, Race, and the Science of Language. (London; New York: Routledge).

Jespersen, O. (1960). "Efficiency in Linguistic Change," in Selected Writings of Otto Jespersen (Copenhagen: Levin \& Munskgaard), 381-466.

Jespersen, O. (1922). Language: Its Nature, Development and Origin. London: Allen \& Unwin.

Jespersen, O. (1894). Progress In Language. London: Sonnenschein.

Joseph, J. (2021). Why Does Language Complexity Resist Measurement? Front. Commun. 6, 624855. doi:10.3389/fcomm.2021.624855

Joseph, J. E., and Newmeyer, F. J. (2012). “'All Languages Are Equally Complex': The rise and fall of a consensus". Historiographia Linguistica 39, 341-368. doi:10.1075/hl.39.2-3.08jos

Knobloch, C. (2011). Sprachauffassungen: Studien zur Ideengeschichte der Sprachwissenschaft. Frankfurt am Main: Peter Lang.

Koerner, E.F.K. (1989). "August Schleicher and Linguistic Science in the Second Half of the 19th Century," in Practicing Linguistic Historiography. E.F.K. Koerner (Amsterdam \& Philadelphia: John Benjamins), 324-375.

Lehmann, C. (2015). "Thoughts on Grammaticalization, 3rd edition edn (Berlin: Language Science Press).

McElvenny, J. (2016). The fate of form in the Humboldtian tradition: The Formungstrieb of Georg von der Gabelentz. Lang. Commun. 47, 30-42. doi:10.1016/j.langcom.2015.12.004

McElvenny, J. (2017). Linguistic Aesthetics from the Nineteenth to the Twentieth Century: The Case of Otto Jespersen's "Progress in Language". Hist. Humanities 2, 417-442. doi:10.1086/693322

McElvenny, J. (2018a). August Schleicher and Materialism in 19th-Century Linguistics. Historiographia Linguistica 45, 133-152. doi:10.1075/hl.00018.mce

McElvenny, J. (2018b). Language and Meaning in the Age of Modernism: C.K. Ogden and His Contemporaries. OCLC: on1030902866 (Edinburgh: Edinburgh University Press).

McElvenny, J. (2020). "La grammaticalisation et la circulation internationale des idées linguistiques," in Les linguistes allemands du XIXème siècle et leurs interlocuteurs étrangers. Editor J. François (Paris:Société de Linguistique de Paris), 201-212

McWhorter, J. H. (1998). Identifying the Creole Prototype: Vindicating a Typological Class. Language 74, 788-818. doi:10.2307/417003

McWhorter, J. H. (2001). The world's Simplest Grammars Are Creole Grammars. Linguistic Typol. 5, 125-166. doi:10.1515/lity.2001.001

McWhorter, J. H. (2007). Language Interrupted: Signs of Non-native Acquisition in Standard Language Grammars. OCLC: ocm71509119 (Oxford; New York: Oxford University Press)

McWhorter, J. H. (2011). Linguistic Simplicity and Complexity: Why Do Languages Undress? (Berlin: De Gruyter Mouton).

Morpurgo Davies, A. (1975). "Language Classification in the Nineteenth Century," in Current Trends in Linguistics 13. Historiography of Linguistics. Editor T. A. Sebeok (The Hague: Mouton), Vol. I, 607-716.
Morpurgo Davies, A. (1998). "History of Linguistics. Vol. IV. Nineteenthcentury Linguistics”. Editor G. Lepschy. (OCLC: 833247379. London: Longman).

Plank, F. (1992). "Language and Earth as Recycling Machines," in Language and Earth: Effective Affinities between the Emerging Sciences of Linguistics and Geology. Editors B. Naumann, F. Plank, and G. Hofbauer (Amsterdam: John Benjamins), 221-269. doi:10.1075/sihols.66.13pla

Richards, R. J. (2002). The Romantic Conception of Life: Science and Philosophy in the Age of Goethe. Science and its Conceptual Foundations. Chicago: University of Chicago Press. doi:10.7208/chicago/9780226712185.001. 0001

Richards, R. J. (2008). The Tragic Sense of Life: Ernst Haeckel and the Struggle over Evolutionary Thought. OCLC: 309071386 (Chicago:University of Chicago Press)

Schlegel, A. W. (1818). Observations sur la langue et la littérature provençales. Paris: Librairie grecque-latine-allemande.

Schlegel, F. (1808). Über die Sprache und Weisheit der Indier. London:Mohr und Zimmer

Schleicher, A. (1859). Zur Morphologie der Sprache. St.-Petersbourg:Mémoires de l'Académie Impériale des Sciences de St-Petersbourg I, 1-38.

Schleicher, A. (1860). Die Deutsche Sprache. Stuttgart: Cotta.

Schleicher, A. (1863). Die Darwinsche Theorie und die Sprachwissenschaft, offenes Sendschreiben an Herrn Dr. Ernst Haeckel, o. Professor der Zoologie und Direktor des zoologischen Museums an der Universität Jena. Weimar: Böhlau.

Thomason, S. G., and Kaufman, T. (1988). Language Contact, Creolization, and Genetic Linguistics. Berkeley: University of California Press. doi:10.1525/ 9780520912793

Trabant, J. (1986). “Apeliotes, oder, Der Sinn der Sprache: Wilhelm von Humboldts Sprach-Bild," (München: W. Fink).

Trabant, J. (1990). Traditionen Humboldts. Frankfurt am Main:Suhrkamp

Trabant, J. (2012). Weltansichten: Wilhelm von Humboldts Sprachprojekt. OCLC: ocn811004514 (München: Beck).

Trudgill, P. (1989). "Contact and Isolation in Linguistic Change," in Language Change. Editors L. E. Breivik and E. H. Jahr (Berlin:Mouton De Gruyter), 227-237

Trudgill, P. (2009). "Sociolinguistic Typology and Complexification," in Language Complexity as an Evolving Variable. Editors G. Sampson, D. Gil, and P. Trudgill (Oxford: Oxford University Press), 98-109.

Trudgill, P. (2011). Sociolinguistic Typology: Social Determinants of Linguistic Complexity. Oxford: Oxford University Press.

Conflict of Interest: The author declares that the research was conducted in the absence of any commercial or financial relationships that could be construed as a potential conflict of interest.

Copyright $\odot 2021$ McElvenny. This is an open-access article distributed under the terms of the Creative Commons Attribution License (CC BY). The use, distribution or reproduction in other forums is permitted, provided the original author $(s)$ and the copyright owner(s) are credited and that the original publication in this journal is cited, in accordance with accepted academic practice. No use, distribution or reproduction is permitted which does not comply with these terms. 